\title{
Retrofitting Vectors for Escherichia coli-Based Artificial Chromosomes (PACs and BACs) with Markers for Transfection Studies
}

\author{
José E. Mejía ${ }^{1}$ and Anthony P. Monaco ${ }^{2}$
}

Wellcome Trust Centre for Human Genetics, University of Oxford, Windmill Road, Oxford OX3 7BN, UK

PI-based artificial chromosomes (PACs) and bacterial artificial chromosomes (BACs) have significantly expanded the size of fragments from eukaryotic genomes that can be stably cloned in Escherichia coli as plasmid molecules. Functional characterization of a gene within a given PAC or BAC clone often requires transferring the DNA into eukaryotic cells for transient or long-term expression. To facilitate transfection studies, we have developed protocols using the Notl restriction sites of any PAC or BAC clone to introduce a transfection reporter gene, lacZ, together with a selectable marker, neo. This enables transfected cells to be detected by X-Gal staining to verify DNA uptake, and clones of stably transformed cells may be selected for in the presence of the antibiotic G418. The same retrofitting protocols may be applied with other markers of interest to extend the functionality of PAC and BAC libraries, and specialized aspects of such manipulation of $E$. coli-based artificial chromosomes are outlined.

The bacterial artificial chromosomes (BACs) and P1based artificial chromosomes (PACs) are new vector systems for cloning very large DNA inserts in Escherichia coli, based on replication control elements from factor $\mathrm{F}$ and bacteriophage $\mathrm{P} 1$, respectively (Shizuya et al. 1992; Ioannou et al. 1994). By propagating at a very low copy number per cell, these vectors enable genomic inserts up to $300 \mathrm{~kb}$ in size to be stably maintained, and most clones in human genomic libraries fall within the 100-200 kb size range. This is smaller than the size achieved in yeast artificial chromosomes (YACs), but PACs and BACs are being used successfully in physical mapping and positional cloning projects (Wooster et al. 1995; Schmitt et al. 1996). In sharp contrast to the YAC system, libraries of PACs and BACs are devoid of a high proportion of chimeric or rearranged clones (for review, see Monaco and Larin 1994), and these circular DNA molecules are easily isolated from the host genomic background in a classical alkaline lysis plasmid preparation (Birnboim and Doly 1979).

PACs and BACs show considerable promise for use in functional studies of cloned genes and their products, where transfer of extensive DNA sequences into eukaryotic cells may be necessary. The large insert size makes it possible for many genes to

\footnotetext{
'Present address: Institute of Molecular Medicine, John Radcliffe Hospital, Oxford OX3 9DU, UK.

2Corresponding author.

E-MAlL anthony.monaco@well.ox.ac.uk; FAX (+44 1865) 742186.
}

be represented in full within a single clone, including distant or intronic transcription control elements. Following transfection, it is necessary to distinguish the cells that have taken up cloned DNA from the background of nontransformed cells. The vectors used in the preparation of PAC and BAC libraries, however, lack relevant reporter genes, and the absence of genes whose expression can be selected for in eukaryotic cells precludes the isolation of stably transfected clones.

In this work, we have developed novel retrofitting procedures for modifying individual PAC and BAC clones to render them suitable for transfection experiments. We have constructed a DNA cassette encompassing the $\beta$-galactosidase $(\operatorname{lac} Z$ ) and aminoglycoside phosphotransferase (neo) genes together with control sequences for transcription in eukaryotic cells; expression of these genes in transfected cells permits blue staining using the chromogenic substrate X-Gal and clone selection in the presence of the antibiotic G418, respectively. The DNA cassette is integrated into PACs and BACs by using restriction sites flanking the insert in both the PAC and BAC vectors, and two different protocols have been optimized depending on the restriction pattern of the genomic insert. These protocols greatly expand the functionality of $E$. coli-based artificial chromosomes, particularly the existing human libraries (Shizuya et al. 1992; Ioannou and de Jong 1996; Kim et al. 1996), totaling >10 genome 


\section{MEIÍA AND MONACO}

equivalents, and set patterns for manipulating these large DNA molecules much like the smaller, more familiar plasmid vectors.

\section{RESULTS}

The DNA cassette constructed with the neo and lacZ genes as markers for transfection studies is illustrated in Figure 1A. A third gene, cat, encoding chloramphenicol acetyltransferase, is present in the construction as a selective marker conferring chloramphenicol resistance to $E$. coli cells, and bacterial expression of the neo gene brings about resistance to kanamycin. PACs and BACs carry a single resistance marker: Either the kanamycin resistance gene from Tn903 (PAC) or the cat gene (BAC), and it was possible to use a combination of chloramphenicol and kanamycin to select for the integration of the retrofitting cassette into a given PAC or BAC.

Flanking NotI sites were engineered so that the neo, lacZ, and cat expression units could be excised as a single DNA fragment and ligated to the NotI sites flanking the genomic insert in both the PAC and BAC vectors (Fig. 1B). NotI cleaves mammalian genomic DNA very rarely, and in a high proportion of PAC and BAC clones it is therefore possible to excise the respective genomic insert as a single NotI fragment. Two different protocols were developed to integrate the retrofitting cassette into precisely defined locations within any PAC or BAC clone, depending on the presence of internal NotI sites in the genomic insert.

\section{Vector Exchange}

In the vector exchange procedure, genomic inserts devoid of internal NotI sites were excised with this enzyme and subcloned in the specialized vector pJMOx166 (Fig. 2). This was constructed by fusing a copy of the DNA cassette to the pCYPAC2 PAC vector (Ioannou and de Jong 1996) (Fig. 1B) and deleting one of the two NotI sites. The $s a c B$ gene in PCYPAC2, part of a selection mechanism against nonrecombinant clones during the preparation of PAC libraries (Ioannou et al. 1994), was also deleted in this step. To assess the efficiency of the vector exchange protocol, this was applied to one $\mathrm{BAC}$ and one PAC clone from human genomic libraries.

The 95-kb insert from BAC 24 was released from the vector as a single NotI fragment and ligated to

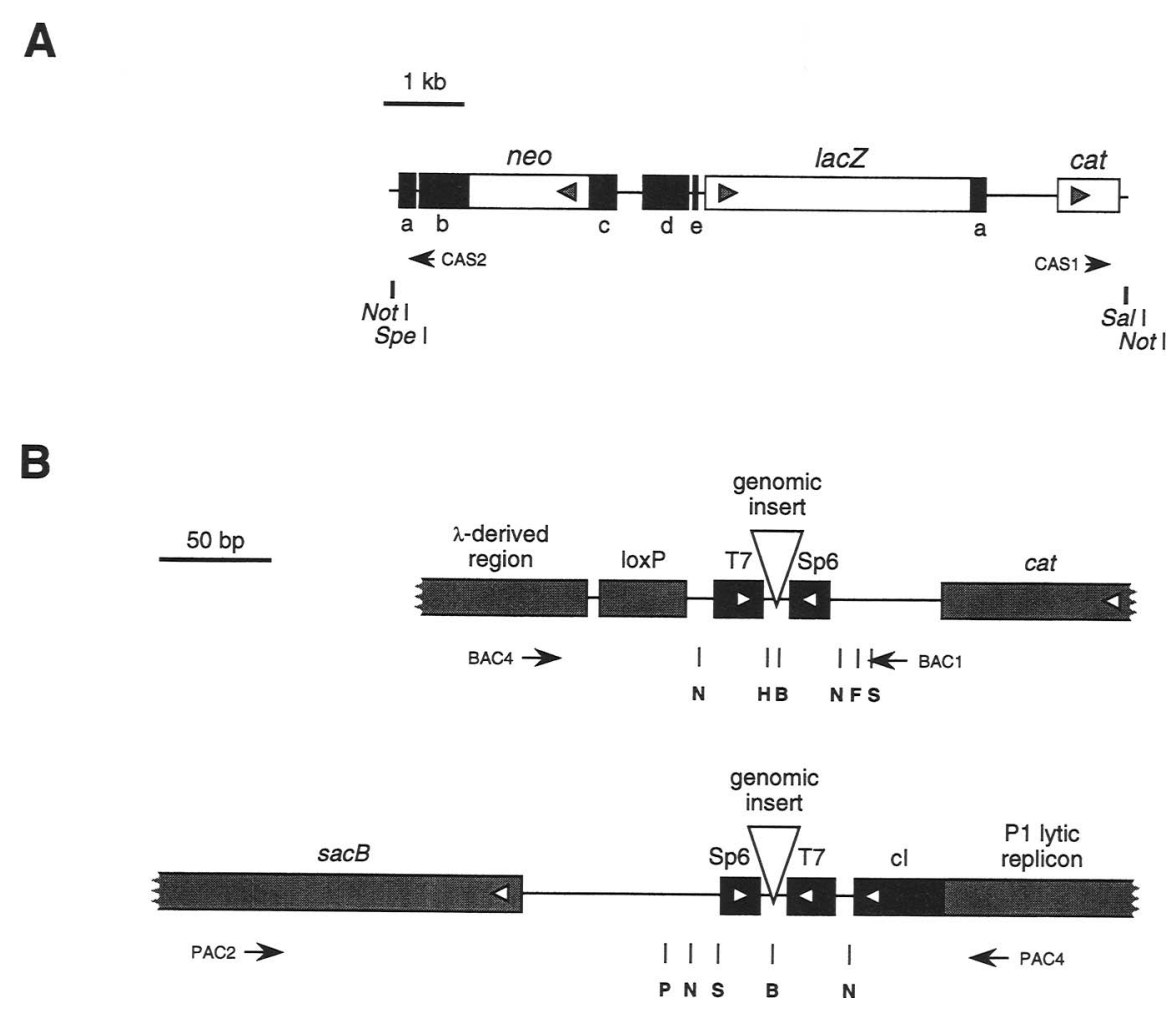

Figure 1 (A) Schematic representation of the neo-lacZ-cat retrofitting cassette from pJMOx5.9. Sequences for expression of the neo and lacZ genes in eukaryotic cells are shown as solid boxes: (a) Polyadenylation signals; (b) t antigen intron; (c) early gene promoter with origin of replication; (e) late gene splice site, all from SV40; lacZ is transcribed from the major immediate-early gene promoter/enhancer of human cytomegalovirus (d). Arrowheads inside the white boxes denote the direction of transcription of the respective genes. Arrows show the position of the target sequences for the CAS1 and CAS2 PCR primers. The flanking Notl sites are indicated, together with unique, terminal restriction sites within the cassette for Spel and Sall. (B) Maps of the cloning site region of BAC and PAC vectors. (Top) pBAC108L (Shizuya et al. 1992); (bottom) pCYPAC2 (loannou and de Jong 1996). Arrowheads denote the direction of transcription of flanking genes and the orientation of Sp6 and T7 promoters. The bacterial promoter for the $\operatorname{sac} B$ gene with a binding site for the $\lambda d$ repressor is also shown. The position and orientation of PCR primers used in this work are indicated by arrows. The sites for the following restriction enzymes are also shown: (N) Notl; (H) Hindlll; (B) BamHl; (F) Sfil; (S) Sall; (P) Spel. 
NotI-digested and dephosphorylated pJMOx166 in three different insert-to-vector molar ratios. First, 23 clones derived from each ligation were screened on the basis of the size difference between pJMOx166 and the product desired, by using a short $(2.8 \mathrm{hr})$ pulsed field gel electrophoresis (PFGE) run of undigested DNA; selected clones were analyzed further with NotI. The ligations with insert-to-vector ratios of $1: 2,1: 4$, and $1: 1$ yielded three, six, and seven positive clones, respectively, characterized by a NotI fragment of $95 \mathrm{~kb}$ in addition to the $24-\mathrm{kb}$ vector fragment (Fig. 3A).

In a subsequent experiment, the protocol was applied to PAC 315 with a genomic insert of $150 \mathrm{~kb}$. Notl-digested PAC DNA was ligated to linearized and dephosphorylated pJMOx166 in a single insertto-vector molar ratio of 1:2. Restriction and PFGE screening of only 12 colonies was sufficient to detect two clones positive for the presence of the 150kb segment within pJMOx166 (Fig. 3B). In this experiment transformed cells were plated on agar medium containing $2 \%$ sucrose in addition to kanamycin and chloramphenicol. Sucrose was employed as a selective factor on the basis of the pres-

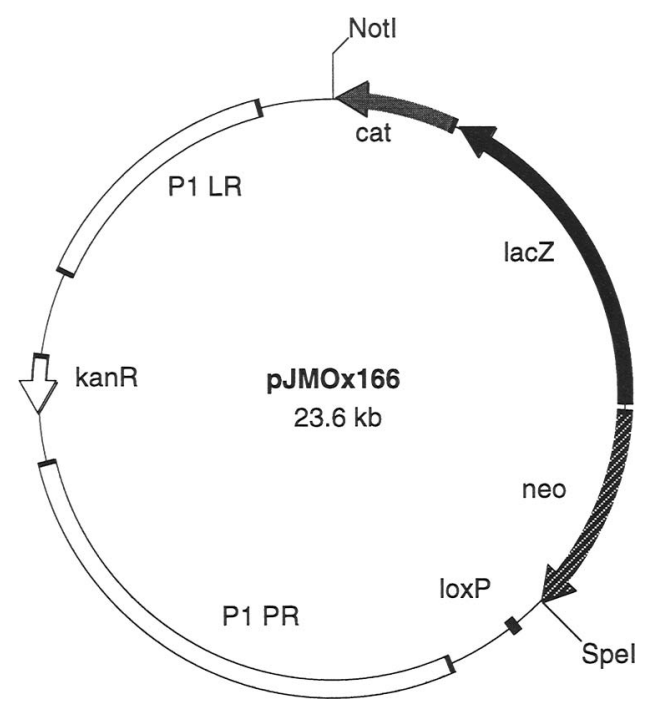

Figure 2 Map of the pJMOx166 vector used in the vector exchange protocol. The unique Notl site used in subcloning genomic inserts is shown at the top. Details of the structure of the cat, lac $Z$, and neo expression units from the DNA cassette can be found in Fig. 1A. The Spel site shows the position of sequences between the $\mathrm{P} 1$ loxP recombination region and the neo unit deleted during the construction of the vector. P1 LR and P1 PR are the lytic replicon and plasmid replicon regions from bacteriophage $\mathrm{P} 1$, respectively. (kanR) Kanamycin resistance gene in the PAC moiety. ence of the Bacillus amyloliquefaciens sacB gene in pCYPAC2, the vector in the PAC library, and the absence of this gene in the product desired. Levansucrase, the enzyme encoded by $s a c B$, uses sucrose to synthesize levan, and expression of $s a c B$ in $E$. coli has been observed to result in cell poisoning when sucrose is added to the culture medium (Steinmetz et al. 1983).

\section{Cassette Insertion}

The cassette insertion procedure was employed with PAC and BAC clones where, because of internal NotI sites, complete NotI digestion would have fragmented the insert. Limiting amounts of NotI were used in this case to cleave the circular DNA molecules at a single site, and the retrofitting cassette was ligated to the resulting DNA ends. The amount of endonuclease was determined empirically using a range of NotI concentrations while keeping the amount of DNA constant. After PFGE analysis of the DNA samples, the most suitable were dialyzed and ligated to the purified retrofitting cassette. Transformed E. coli cells were plated on kanamycin- and chloramphenicol-containing medium to select for the presence of the cassette. The donor molecule in the preparation of retrofitting cassette for these experiments, pJMOx 5.9, was created by subcloning the cassette in the pCYPAC2 vector. The cassette moves as the leading NotI fragment from pJMOx5.9 on preparative agarose gel electrophoresis, reducing the risk of contamination of the cassette band with the vector fragment of $16 \mathrm{~kb}$ (Southern and Elder 1995). Moreover, the presence of the $s a c B$ gene in this vector permitted the use of sucrose for negative selection when the $s a c B$ gene was absent from the construction desired.

Figure 4 shows the PFGE pattern of human BAC 162 digested with serial dilutions of NotI, with products ranging from complete digestion to virtually undigested DNA. Four digestions where most DNA molecules where circular or linearized (Fig. 4, lanes 4-7) were ligated to the purified DNA cassette in three different cassette-to-vector molar ratios, 3:1, $1: 1$, and $1: 3$. The number of transformant colonies, from 12 up to several thousands, was proportional to the degree of NotI digestion of BAC 162 DNA. PFGE analysis of undigested DNA in 72 clones derived from the three ligations with the sample in Figure 4, lane 7, and the 1:3 ligation with the sample in lane 6 failed to detect major deletions of the genomic insert in 70 of these clones. NotI and PFGE analysis was then performed on 18 colonies from each of the 3:1 and 1:1 ligations of the latter sample. 


\section{MEJÍA AND MONACO}

This revealed that the 9- and 140-kb NotI fragments from the genomic insert were present in 17 of 18 clones (Fig. 3C), confirming that cassette insertion had taken place on BAC molecules cleaved at a single site as expected. Analysis of clones derived from further digestions (Fig. 4, lanes 5,4) was thus unnecessary.

A similar experiment was conducted with PAC

A

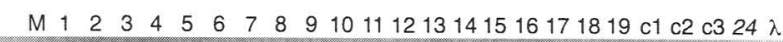
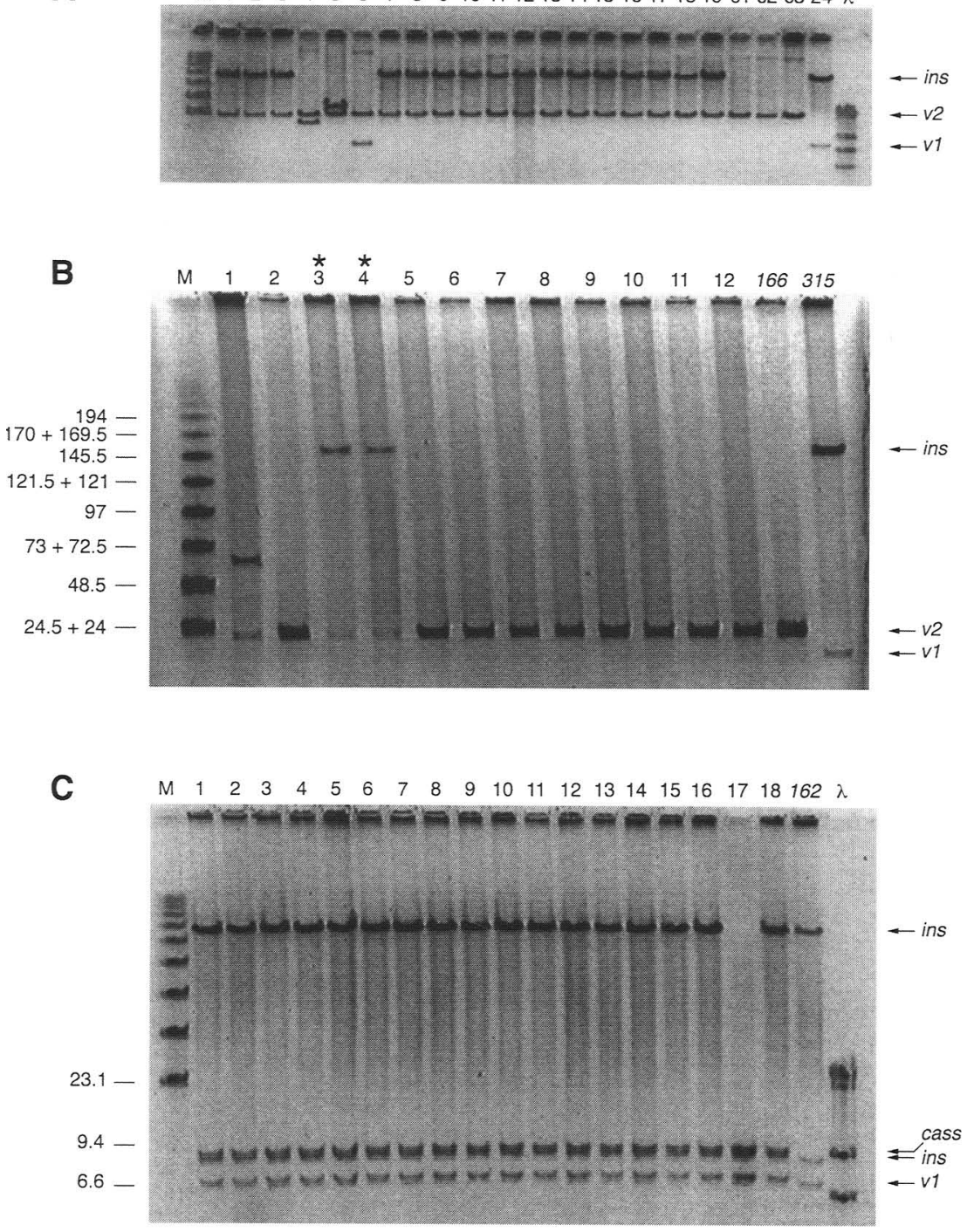

D

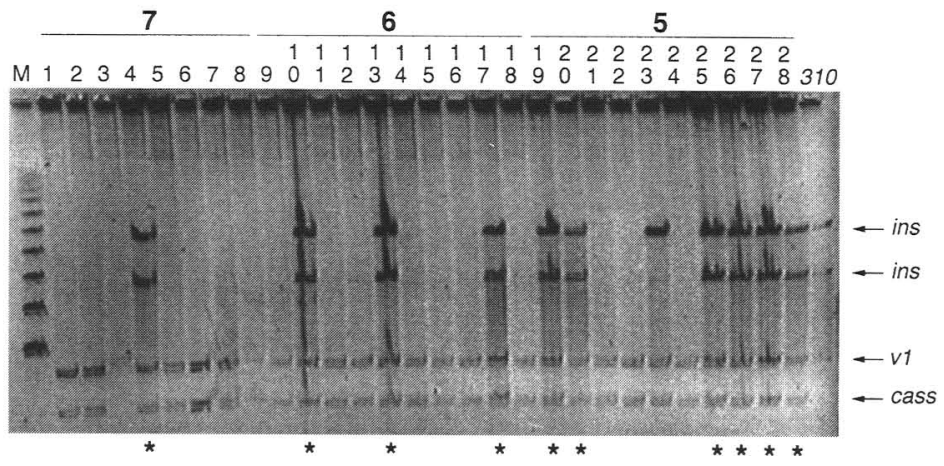

Figure 3 (See facing page for legend.) 
PROCEDURES FOR PAC AND BAC RETROFITTING

310 , encompassing a large genomic insert of $170 \mathrm{~kb}$ yielding $60-$ and $110-\mathrm{kb}$ fragments upon complete NotI digestion. PAC 310 DNA was partially digested and ligated in a single cassette-to-vector molar ratio of 1:3. Again, the number of resulting colonies increased with the degree of digestion, from 24 to 156 . Sucrose was not included in growing medium, as it was anticipated from preliminary studies that insertion of the retrofitting cassette into the NotI site adjoining $s a c B$ would result in transcription of this gene from bacterial promoters in the newly inserted segment. Random clones derived from three digestion stages of PAC 310 were analyzed by NotI restriction and PFGE, which showed that the cassette had been inserted without any loss of genomic segments in 1 clone out of 8 from digestion 7, 3 out of 10 from digestion 6 , and 6 out of the 10 from digestion 5 (Fig. 3D).

The insertion of the neo-lacZ-cat retrofitting cassette may occur in any of the NotI sites of the target artificial chromosome, including those within the genomic insert. Further analysis of cassette insertion events was therefore required to determine the site of insertion. Oligonucleotide primers adjoining the NotI site in the PAC vector (Fig. 1B) were combined with primers specific for the terminal regions of the retrofitting cassette (Fig. 1A) in a series of four PCR amplifications. Complete absence of PCR products from a retrofitted clone was interpreted as a disruption of the genomic insert by the cassette. On the contrary, suitable clones were expected to yield one of the four possible cassettevector junction fragments created by ligation of the cassette, in two possible orientations, to either of the NotI sites outside the genomic insert. Of 11 such clones, 1 was identified from PAC 310, and 12 of 24 clones were identified from BAC 162 (data not shown).

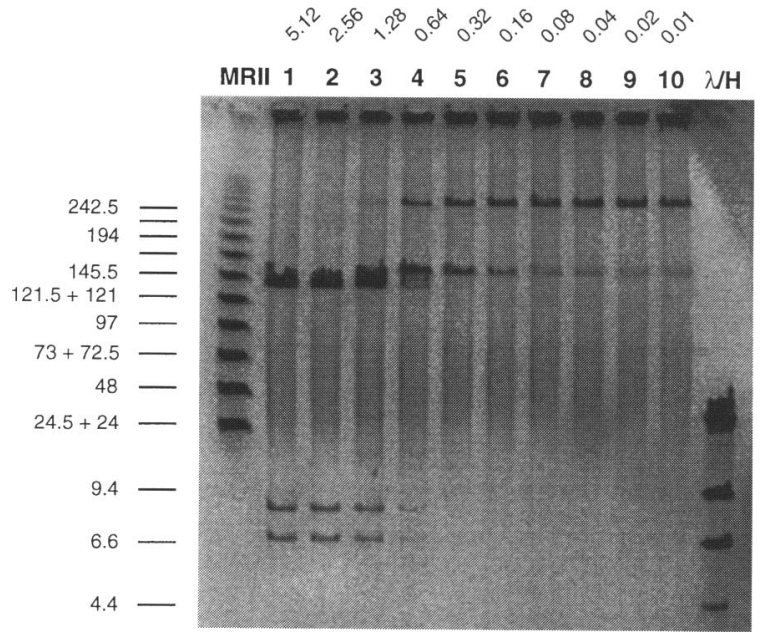

Figure 4 PFGE analysis of BAC 162 DNA digested with serially diluted Notl. Enzyme concentration decreases from left to right as indicated at the top $(\mathrm{U} / \mu \mathrm{g}$ DNA). Complete digestion (lanes 1,2 ) yields fragments of $\sim 140$ and $9 \mathrm{~kb}$ from the insert, in addition to the vector fragment of $6.9 \mathrm{~kb}$. The sizes of the fragments in the DNA size standards are indicated at left. (MRII) MidRange II PFGE marker (New England Biolabs); $(\lambda / \mathrm{H}) \lambda$ DNA digested with HindIII.

To confirm that the retrofitting cassette would function in mammalian cells, PACs and BACs were transfected into the human fibrosarcoma cell line HT-1080 (Rasheed et al. 1974). X-Gal staining after $48 \mathrm{hr}$ showed intense blue staining in $4.5 \%-10 \%$ of the cells (L. Porter, J.E. Mejía, and A.P. Monaco, unpubl.). Following 10 days of culture in the presence of G418 antibiotic ( $400 \mu \mathrm{g} / \mathrm{ml}$ ) (Southern and Berg $1982), 10-20$ colonies were identified per $10-\mathrm{cm}-$ diameter dish; the structure of recombinant DNA integrated into the cellular genome was not determined.

Figure 3 Screening of clones from retrofitting experiments by Notl digestion and PFGE analysis. DNA from the parental artificial chromosome was included as a control (right). Size markers: MidRange II PFGE marker from New England Biolabs (M); HindIII digestion of $\lambda$ DNA $(\lambda)$; the sizes of the DNA fragments $(k b)$ are indicated to the left of panels $B$ and $C$, respectively. Arrows denote the positions of the fragments corresponding to the genomic insert (ins), the original BAC or PAC vector (v1), the retrofitting vector pJMOX166 (v2) in the vector exchange protocol $(A, B)$, and the retrofitting cassette (cass) in the cassette insertion protocol $(C, D)$. $(A)$ Vector exchange on the genomic insert of BAC 24. The photograph shows the analysis of 19 clones selected previously on the basis of size; a full-length insert is present in lanes 1-3 and 7-19. (c1-c3) Control samples from a ligation involving pJMOX166 alone. (B) Application of the vector exchange procedure to PAC $315 ; 12$ clones were screened for the presence of the genomic insert; positive clones are indicated by asterisks (*). (166) pJMOx166 DNA cut with Notl. (C) Insertion of the retrofitting cassette into BAC 162. The electrophoretic mobility of the smaller insert fragment is close to that of the cassette. Both insert fragments were present in 17 of the 18 clones analyzed; the clone in lane 17 shows a deletion of the larger insert fragment. $(D)$ Insertion of the retrofitting cassette into PAC 310 . Results from three different ligations $(7,6,5)$ are shown (see text for details). 


\section{DISCUSSION}

The experimental procedures that we have described are based on the same methods of enzymatic manipulation of DNA used for plasmid construction in E. coli. Specific modifications of this methodology, however, were called for by the significantly larger size of artificial chromosomes. As the sensitivity of DNA molecules to shearing increases with size, precautions of handling were taken, including the use of drop dialysis as a gentle method of buffer exchange. Pipetting and vortexing were kept to a minimum during the isolation of PAC and BAC DNA, and wide-bore micropipette tips were used throughout. Other consequences of the increased size, as compared with plasmid cloning, were the higher amounts of PAC or BAC DNA used in enzymatic reactions to achieve adequate molar concentrations, and the need for electroporation to transfer ligation products into highly competent $E$. coli cells. We have shown that DNA clones $>180 \mathrm{~kb}$ in size may be efficiently retrofitted by these methods. PFGE was crucial in analyzing such DNA molecules, which widely exceed the range of resolution of standard agarose gels.

The protocols are robust enough so that smallscale screening, by restriction analysis of miniprep DNA, is sufficient to identify at least one bacterial clone containing the desired DNA construction. This efficiency rests on the application of a double antibiotic selection to exclude the parental artificial chromosome from the population of transformed clones. In the vector exchange protocol, however, dephosphorylation of pJMOx166 following NotI digestion is essential in preventing a high background from nonrecombinant vector. In some instances, a second selection factor was at play in reducing background; this was based on the toxic effects of sucrose toward $E$. coli cells expressing the $s a c B$ gene. Sucrose was omitted when $s a c B$ was retained in the retrofitted product, that is, in the cassette insertion experiment with PAC 310 . Although a higher proportion of negative clones was observed in this case, as compared with cassette insertion into BAC 162, a suitable derivative of PAC 310 was identified by using the same small-scale screening method.

The cassette insertion procedure entails a risk for the genomic insert to be disrupted every time an internal NotI site is involved. The outcome of the experiment, expressed as the proportion of nondisrupted inserts among positive clones, will depend on the rates of cleavage of the internal NotI sites relative to the flanking sites. In this respect, variation is conceivable among individual PACs and
BACs, and this was observed between PAC 310 and BAC 162 when the insertion sites were determined by PCR screening.

Although cassette insertion was used in this study on clones that were unsuitable for vector exchange, the former protocol may be applied to any $\mathrm{PAC}$ or BAC, especially when vector replacement is not desirable. This protocol is also versatile in that additional markers may be introduced as needed into artificial chromosomes in successive insertion steps, simply by constructing new DNA cassettes with terminal NotI sites. Moreover, each of these steps would bring about a new NotI site, increasing the number of acceptable insertion sites outside the genomic segment. Both retrofitting protocols for $E$. coli-based artificial chromosomes should prove particularly useful as regards the extensive human genomic libraries available at this time, but they are applicable to libraries from any organism prepared in the same PAC or BAC vectors. Potential uses include the study of the regulation of the expression of a cloned gene, or a group of cocloned adjacent genes, and complementation of molecular defects by transfection. Retrofitting vectors with different combinations of reporter genes and selectable markers will be required, and several of these are under construction.

\section{METHODS}

\section{DNA Preparation and Analysis}

PAC or BAC DNA was isolated in a modified alkaline lysis protocol (Birnboim and Doly 1979) from bacteria grown in $2 \times$ TY medium supplemented with $30 \mu \mathrm{g} / \mathrm{ml}$ of kanamycin or $20 \mu \mathrm{g} / \mathrm{ml}$ of chloramphenicol, respectively. PFGE analysis of PAC and BAC DNA was performed with the CHEF DRII system from Bio-Rad. In most cases, samples were run for $18-20 \mathrm{hr}$ on $1 \%$ agarose gels using $0.5 \times$ standard Tris-borate EDTA (TBE) buffer, at $14^{\circ} \mathrm{C}$; the settings were $200 \mathrm{~V}(\sim 6 \mathrm{~V} / \mathrm{cm})$ and a linear pulse time ramp from 2 to $15 \mathrm{sec}$, with a pulse angle of $120^{\circ}$. The gels were subsequently stained with ethidium bromide for photography.

\section{Construction of Retrofitting Vectors}

A retrofitting cassette was assembled in a plasmid cloning vector with a polylinker flanked by two NotI sites. The $\beta$-galactosidase gene (lacZ) and accompanying mammalian regulation sequences from $\mathrm{pCMV} \beta$ (MacGregor and Caskey 1989) (Clontech) were fused to a similar expression unit for aminoglycoside phosphotransferase from pSV2neo (Southern and Berg 1982) and to the cat gene from the BAC vector pBAC108L (Shizuya et al. 1992). Irrelevant NotI sites were destroyed so that digestion with this enzyme excises the $l a c Z$, neo, and cat genes as a single DNA fragment of $9.2 \mathrm{~kb}$ (Fig. 1A). Subcloning this fragment in the PAC vector pCYPAC2 (Ioannou and de Jong 1996) linearized with Not I yielded pJMOx5.9, used in the cassette insertion procedure; a ho- 
mologous clone with the cassette in reverse orientation was modified by deleting two Spel fragments comprising the $s a c B$ gene in the PAC vector and one of the NotI sites flanking the retrofitting cassette. The resulting molecule, pJMOx166 (Fig. 2), retains a unique NotI site at the other end of the cassette for use in the vector exchange procedure.

\section{Bacterial Transformation}

Transformation of E. coli cells was carried out with a Bio-Rad Gene Pulser electroporation apparatus. Twenty microliters of bacterial suspension was mixed with the DNA solution and transferred to an ice-cold cuvette with a $0.1-\mathrm{cm}$ gap. Electroporation was carried out with the settings $1.8 \mathrm{kV}, 200 \Omega$, and $25 \mu \mathrm{F}$, and $0.5 \mathrm{ml}$ of SOC medium was added to the cuvette immediately after the pulse. The cells were transferred to a microcentrifuge tube and incubated at $37^{\circ} \mathrm{C}$ for $1 \mathrm{hr}$ before plating on selective medium. Electrocompetent $E$. coli DH10B cells (loannou and de Jong 1996) from GIBCO-BRL were used throughout.

\section{Cassette Insertion Procedure}

The neo-lacZ-cat retrofitting cassette was inserted in PAC and BAC clones partially digested with NotI as follows. The enzyme was serially diluted 1:2 in digestion buffer, and a fixed amount of PAC or BAC DNA in 20-25 $\mu$ l of buffer was added to $5 \mu \mathrm{l}$ of diluted NotI. For a series of 10 digestions, the enzyme-to-substrate ratio ranged from 5.12 down to $0.01 \mathrm{U} / \mu \mathrm{g}$ of DNA, with a final DNA concentration of 50 and $200 \mathrm{ng} / \mu \mathrm{l}$ for PAC 310 and BAC 162 , respectively. The reactions were carried out for $2 \mathrm{hr}$ at $37^{\circ} \mathrm{C}$. The enzyme was heat-inactivated at $65^{\circ} \mathrm{C}$ for $10 \mathrm{~min}$, and the extent of the digestion was determined by PFGE analysis. DNA samples digested with 0.64 , $0.32,0.16$, and 0.08 units of NotI/ $\mu$ g of DNA, respectively, were drop-dialyzed with Millipore V series membranes (13mm-diam. discs, pore size $0.025 \mu \mathrm{m}$, catalog no. VSWP 013 $00)$ as recommended by the manufacturer. Briefly, the membrane was floated on $5 \mathrm{~mm}$ Tris- $\mathrm{HCl}(\mathrm{pH} 8)$ and $0.5 \mathrm{~mm}$ EDTA buffer $(0.5 \times \mathrm{TE})$, shiny side up, and a $20-\mu 1$ droplet of DNA solution was laid in the center of the disc. Following dialysis for $2 \mathrm{hr}$ at room temperature, the DNA sample was ligated to gel-purified retrofitting cassette. Each ligation reaction involved $600 \mathrm{ng}$ of vector DNA and 600 units of T4 DNA ligase (New England Biolabs) in a volume of $20 \mu \mathrm{l}$. The ligation buffer was $40 \mathrm{~mm}$ Tris- $\mathrm{HCl}$ ( $\mathrm{pH} 7.5$ ), $10 \mathrm{mM} \mathrm{MgCl}_{2}, 10 \mathrm{~mm}$ dithiothreitol, $0.5 \mathrm{~mm} \mathrm{ATP}$, and $50 \mu \mathrm{g} / \mathrm{ml}$ of BSA (Tabor 1996). The reactions were performed at $16^{\circ} \mathrm{C}$ for $16 \mathrm{hr}$ and were followed by heat-inactivation of ligase at $65^{\circ} \mathrm{C}$ for 10 min. The samples were drop-dialyzed against water and used to transform electrocompetent $E$. coli cells. The cells were plated on $2 \times$ TY agar with $0.2 \%$ glycerol, $20 \mu \mathrm{g} / \mathrm{ml}$ of chloramphenicol, $30 \mu \mathrm{g} / \mathrm{ml}$ of kanamycin, and, for BAC 162, $2 \%$ sucrose.

\section{Vector Exchange Procedure}

In the vector exchange procedure, inserts from PAC and BAC clones were transferred into the PJMOx166 PAC vector as fol-

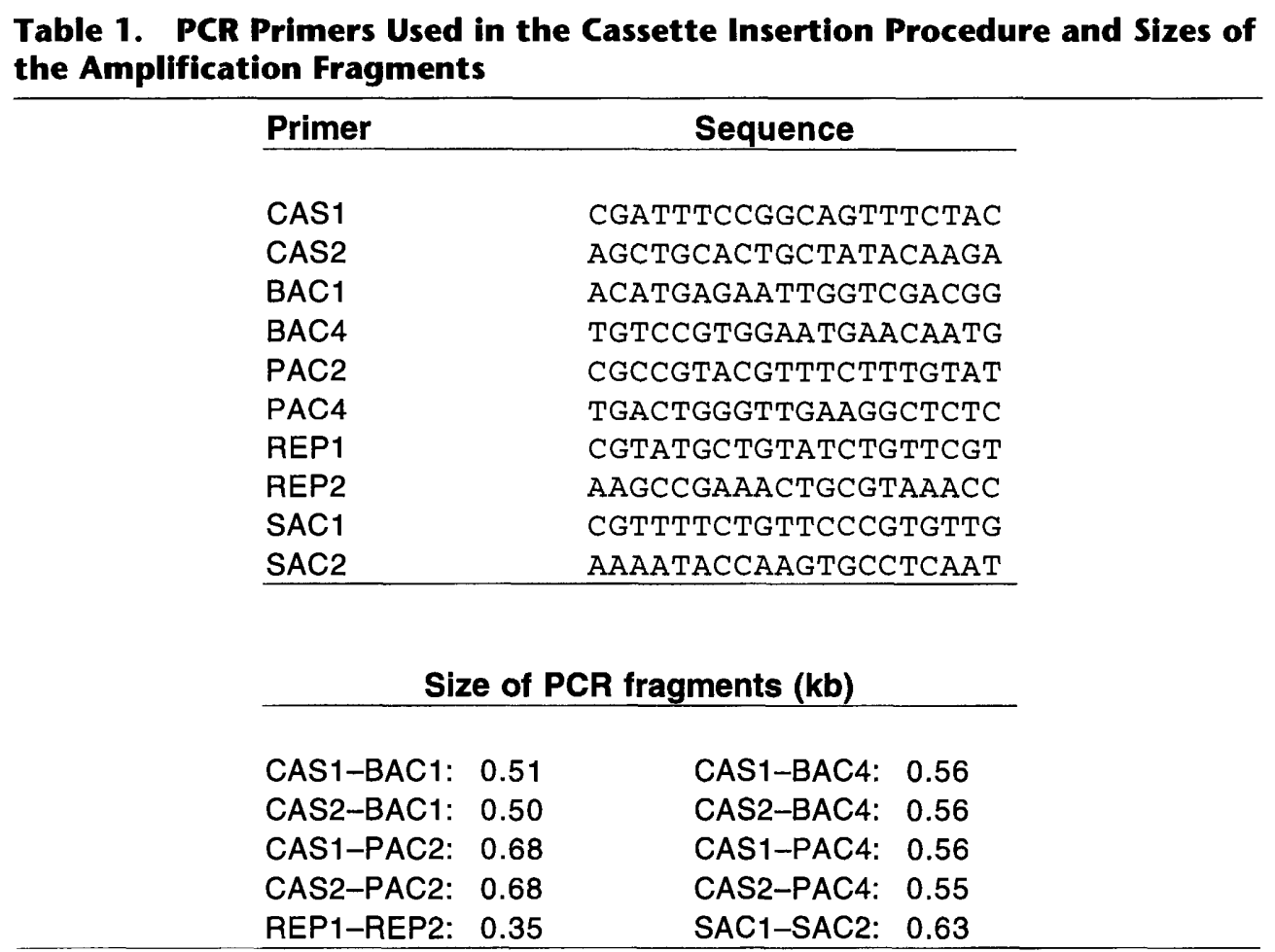

The REP and SAC primer pairs were used in positive control reactions amplifying a fragment of the vector moiety: part of the repE gene (Shizuya et al. 1992) in any BAC clone, or a segment of the sacB gene in any PAC (loannou et al. 1994). 


\section{MEIÍA AND MONACO}

lows. First, NotI digestion and dephosphorylation of $24 \mu \mathrm{g}$ of pJMOx166 DNA were performed in $240 \mu$ of $1 \times$ NEBuffer 3 (New England Biolabs) with BSA. Following heat inactivation of NotI, 1.8 units of calf intestinal phosphatase (Boehringer Mannheim) was added for $30 \mathrm{~min}$ at $37^{\circ} \mathrm{C}$. The phosphatase was inactivated by successive extractions with phenol, phenol-chloroform (1:1), and chloroform. The vector was precipitated with isopropanol, resuspended in $60 \mu \mathrm{l}$ of $1 \times \mathrm{TE}$ buffer and used in ligation reactions at a fixed concentration of $7 \mathrm{ng} / \mu \mathrm{l}$. PAC and BAC DNA was digested to completion with NotI and drop-dialyzed against $0.5 \times \mathrm{TE}$ buffer. For BAC 24 DNA, 280, 570, and 1120 ng were mixed with dephosphorylated vector to achieve $\mathrm{BAC} /$ vector molar ratios of $1: 4$, $1: 2$, and $1: 1$, respectively, and 800 units of T4 DNA ligase was used in 40- $\mu 1$ ligation reactions. As for PAC 315, a PAC/vector molar ratio of $1: 2$ was obtained by introducing $480 \mathrm{ng}$ of NotI-digested DNA in a $20-\mu 1$ reaction with 400 units of T4 DNA ligase. Other details of ligation, dialysis, and transformation of E. coli cells were as described in the cassette insertion procedure. Transformed cells were plated in the presence of chloramphenicol and kanamycin; agar medium also included $2 \%$ sucrose in the experiment with PAC 315.

\section{PCR Amplification}

The site of cassette insertion into a PAC or a BAC clone was mapped by PCR using a primer specific for either end of the retrofitting cassette with a primer annealing to either side of the cloning site of the vector to amplify putative junction regions. The oligonucleotide primers used are listed in Table 1 , together with the sizes of amplification products. The reactions were set up in a hot start protocol (Chou et al. 1992) with the following settings: denaturation at $94^{\circ} \mathrm{C}$ for $30 \mathrm{sec}$, annealing for $40 \mathrm{sec}$, and $72^{\circ} \mathrm{C}$ for $30 \mathrm{sec}$. The annealing temperature was lowered from $55^{\circ} \mathrm{C}$ down to $50^{\circ} \mathrm{C}$ at the rate of $1^{\circ} \mathrm{C} /$ cycle (Don et al. 1991), and 34 additional cycles were carried out at $50^{\circ} \mathrm{C}$. The reactions were analyzed by agarose gel electrophoresis.

\section{ACKNOWLEDGMENTS}

We thank Drs A. Hovnanian, M. Vaxillaire, and M.R. James (Wellcome Trust Centre for Human Genetics, Oxford), for the gift of DNA clones and for helpful discussion. This work was supported by a grant from the Medical Research Council. A.P.M. is a Wellcome Trust Principal Research Fellow.

The publication costs of this article were defrayed in part by payment of page charges. This article must therefore be hereby marked "advertisement" in accordance with 18 USC section 1734 solely to indicate this fact.

\section{REFERENCES}

Birnboim, H.C. and J. Doly. 1979. A rapid alkaline extraction procedure for screening recombinant plasmid DNA. Nucleic Acids Res. 7: 1513-1523.

Chou, Q., M. Russell, D.E. Birch, J. Raymond, and W. Bloch. 1992. Prevention of pre-PCR mis-priming and primer dimerization improves low-copy-number amplifications. Nucleic Acids Res. 20: 1717-1723.

Don, R.H., P.T. Cox, B.J. Wainwright, K. Baker, and J.S. Mattik. 1991. "Touchdown" PCR to circumvent spurious priming during gene amplification. Nucleic Acids Res. 19: 4008 .

Ioannou, P.A. and P.J. de Jong. 1996. Construction of bacterial artificial chromosome libraries using the modified P1 (PAC) system. In Current protocols in human genetics (ed. N.C. Dracopoli, J.L. Haines, B.R. Korf, D.T. Moir, C.C. Morton, C.E. Seidman, J.G. Seidman, and D.R. Smith), pp. 5.15.1-5.15.24. John Wiley \& Sons, New York, NY.

Ioannou, P.A., C.T. Amemiya, J. Garnes, P.M. Kroisel, H. Shizuya, C. Chen, M.A. Batzer, and P.J. de Jong. 1994. A new bacteriophage P1-derived vector for the propagation of large human DNA fragments. Nature Genet. 6: 84-89.

Kim, U.-J., B.W. Birren, T. Slepak, V. Mancino, C. Boysen, H.-L. Kang, M.I. Simon, and H. Shizuya. 1996. Construction and characterization of a human bacterial artificial chromosome library. Genomics 34: 213-218.

MacGregor, G.R. and C.T. Caskey. 1989. Construction of plasmids that express $E$. coli $\beta$-galactosidase in mammalian cells. Nucleic Acids Res. 17: 2365.

Monaco, A.P. and Z. Larin. 1994. YACs, BACs, PACs, and MACs: Artificial chromosomes as research tools. Trends Biotechnol. 12: 280-286.

Rasheed, S., W.A. Nelson-Rees, E.M. Toth, P. Arnstein, and M.B. Gardner. 1974. Characterization of a newly derived human sarcoma cell line (HT-1080). Cancer 33: 1027-1033.

Schmitt, H., U.-J. Kim, T. Slepak, N. Blin, M.I. Simon, and H. Shizuya. 1996. Framework for a physical map of the human 22q13 region using bacterial artificial chromosomes. Genomics 33: 9-20.

Shizuya, H., B. Birren, U.-J. Kim, V. Mancino, T. Slepak, Y. Tachiiri, and M. Simon. 1992. Cloning and stable maintenance of 300-kilobase-pair fragments of human DNA in Escherichia coli using an F-factor-based vector. Proc. Natl. Acad. Sci. 89: 8794-8797.

Southern, P.J. and P. Berg. 1982. Transformation of mammalian cells to antibiotic resistance with a bacterial gene under control of the SV40 early region promoter. $J$. Mol. Appl. Genet. 1: 327-341.

Southern, E.M. and J.K. Elder. 1995. Theories of gel electrophoresis of high molecular weight DNA. In Pulsed field gel elecrophoresis (ed. A.P. Monaco), pp. 1-19. IRL Press, Oxford, UK.

Steinmetz, M., D. Le Coq, H. Ben Djemia, and P. Gay. 1983. Analyse génétique de $s a c B$, gène de structure d'une enzyme sécrétée, la lévane-saccharase de Bacillus subtilis Marburg. Mol. \& Gen. Genet. 191: 138-144.

Tabor, S. 1996. DNA ligases. In Current protocols in molecular biology (ed. F.A. Ausubel, R. Brent, R.E. Kingston, D.D. Moore, J.G. Seidman, J.A. Smith, and K. Struhl), pp. 3.14.1-3.14.4. John Wiley \& Sons, New York, NY.

Wooster, R., G. Bignell, J. Lancaster, S. Swift, S. Seal, J. Mangion, N. Collins, S. Gregory, C. Gumbs, G. Micklem, et al. 1995. Identification of the breast cancer susceptibility gene BRCA2. Nature 378: 789-792.

Received September 11, 1996; accepted in revised form December 17, 1996. 


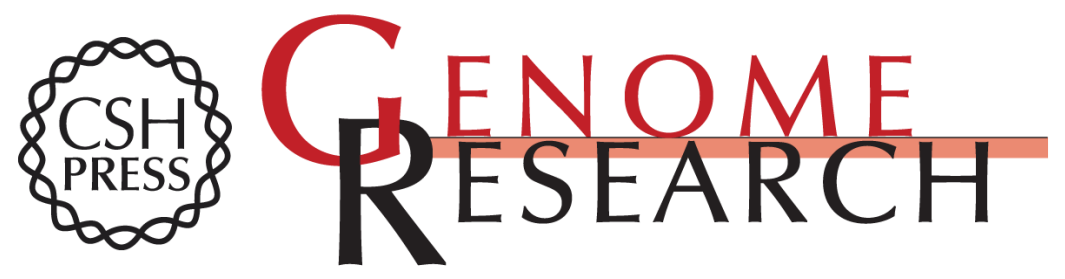

\section{Retrofitting vectors for Escherichia coli-based artificial chromosomes (PACs and BACs) with markers for transfection studies.}

J E Mejía and A P Monaco

Genome Res. 1997 7: 179-186

Access the most recent version at doi:10.1101/gr.7.2.179

References This article cites 13 articles, 1 of which can be accessed free at:

http://genome.cshlp.org/content/7/2/179.full.html\#ref-list-1

\section{License}

Email Alerting

Receive free email alerts when new articles cite this article - sign up in the box at the Service top right corner of the article or click here.

\section{Affordable, Accurate Sequencing.}

To subscribe to Genome Research go to:

https://genome.cshlp.org/subscriptions 